\title{
Expression of $\beta$-Amyloid Induced Age-Dependent Presynaptic and Axonal Changes in Drosophila
}

\author{
Xiao-Liang Zhao, ${ }^{1 *}$ Wen-An Wang, ${ }^{2 *}$ Jiang-Xiu Tan, ${ }^{1}$ Jian-Kang Huang, ${ }^{3}$ Xiao Zhang, ${ }^{1}$ Bao-Zhu Zhang, ${ }^{1}$ \\ Yu-Hang Wang, ${ }^{1}$ Han-Yu YangCheng, ${ }^{1}$ Hong-Lian Zhu, ${ }^{3}$ Xiao-Jiang Sun, ${ }^{3}$ and Fu-De Huang ${ }^{1}$ \\ ${ }^{1}$ Institute of Neuroscience and State Key Laboratory of Neuroscience, Shanghai Institutes for Biological Sciences, Chinese Academy of Sciences, Shanghai \\ 200031, China, ${ }^{2}$ Department of Neurology, Xin Hua Hospital affiliated with Shanghai Jiaotong University School of Medicine, Shanghai 200233, China, and \\ ${ }^{3}$ Department of Neurology, The Sixth People's Hospital affiliated with Shanghai Jiaotong University, Shanghai 200092, China
}

\begin{abstract}
Alzheimer's disease $(\mathrm{AD})$ is attributable to synapse dysfunction and loss, but the nature and progression of the presynaptic structural and functional changes in $\mathrm{AD}$ are essentially unknown. We expressed wild-type or arctic form of $\beta$ amyloid $_{1-42}(\mathrm{~A} \beta)$ in a small group of neurons in the adult fly and performed extensive time course analysis of the function and structure of both axon and presynaptic terminals at the identified single-neuron level. $\mathrm{A} \beta$ accumulated intracellularly and induced a range of age-dependent changes, including depletion of presynaptic mitochondria, slowdown of bi-directional transports of axonal mitochondria, decreased synaptic vesicles, increased large vacuoles, and elevated synaptic fatigue. These structural and functional synaptic changes correlated with age-dependent deficit in motor behavior. All these alterations were accelerated in flies expressing the arctic form of A $\beta$. The depletion of presynaptic mitochondria was the earliest detected phenotype and was not caused by the change in axonal transport of mitochondria. Moreover, axonal mitochondria exhibited a dramatic reduction in number but a significant increase in size in aged $\mathrm{A} \beta$-expressing flies, indicating a global depletion of mitochondria in the neuron and an impairment of mitochondria fission. These results suggest that $A \beta$ accumulation depletes presynaptic and axonal mitochondria, leading to other presynaptic deficits.
\end{abstract}

\section{Introduction}

Alzheimer's disease (AD) is the most common form of dementia in elderly people. The AD brains show the presence of neural fibrillary tangles (NFTs) and extracellular senile plaques, as well as the loss of synapses and neurons. In AD animal models and patients, synapse loss exhibited a stronger correlation with cognitive deficits and occurred earlier than plaques, NFTs, and neuron loss (Terry et al., 1991; Sze et al., 1997; Mucke et al., 2000; Scheff and Price, 2006). Thus, it is widely believed that synapse dysfunction and loss represent the cellular basis of cognitive deficits (Small et al., 2001; Hardy and Selkoe, 2002; Selkoe, 2002; Shen and Kelleher, 2007).

Since the identification of $\beta$-amyloid $(\mathrm{A} \beta$ ) (Glenner and Wong, 1984) and $\mathrm{A} \beta$ precursor protein (APP) (Kang et al., 1987; Tanzi et al., 1987), several lines of evidence indicate that $\mathrm{A} \beta$ accumulation plays a causal and central role in AD. First, mutations

\footnotetext{
Received July 30, 2009; revised Nov. 4, 2009; accepted Dec. 4, 2009.

This work was supported by the 973 Program Grants 2006CB806600 and 2007CB947101, Knowledge Innovation Engineering Project of the Chinese Academy of Sciences Grant KSCX2-YW-R-099, and Shanghai Municipal Program for Basic Research Grant 06dj14010. We thank Dr. Mu-Ming Poo for suggestions and comments during the preparation of this manuscript, Dr. Q. Hu for technical help during confocal imaging, L. She for help in data analysis, and Dr. CXu, Q.J. Liu, and T.Z. Wang for discussion. We also thank Dr. D. C. Crowther (Cambridge University, Cambridge, UK) for A $\beta$ transgenic flies, and Dr. C. J. O'Kane (Cambridge University) for P[Gal4]A307 flies, and the Drosophila Bloomington Stock Center (University of Indiana, Bloomington, IN) for providing stocks.

${ }^{*}$ X.-L.Z. and W.-A.W. contributed equally to this work.

Correspondence should be addressed to Fu-De Huang, Institute of Neuroscience and State Key Laboratory of Neuroscience, Shanghai Institutes for Biological Sciences, Chinese Academy of Sciences, 320 Yue Yang Road, Shanghai 200031, China. E-mail: fdhuang@ion.ac.cn.

DOI:10.1523/JNEUROSCI.3699-09.2010

Copyright $\odot 2010$ the authors $\quad 0270-6474 / 10 / 301512-11 \$ 15.00 / 0$
}

of APP and APP metabolic enzymes cause familial AD (Selkoe, 2001; Tanzi and Bertram, 2005). Second, both APP and A $\beta$ transgenic animals exhibit $\mathrm{AD}$-like pathology and cognitive impairment (Götz and Ittner, 2008). Third, the soluble A $\beta$ level in AD brains correlates with the extent of cognitive deficits (Lue et al., 1999; McLean et al., 1999). Fourth, A $\beta$ is neurotoxic to cultured neurons (Yankner et al., 1990; Pike et al., 1993), brain slices, and animal brains (Walsh et al., 2002; Selkoe, 2008; Shankar et al., 2008). Finally, reducing cerebral $A \beta$ improves the pathological and cognitive deficits in AD animal models (Morgan et al., 2000; Weiner and Frenkel, 2006).

Before the synapse loss in AD patients and animal models, there must be functional and structural changes at the synapse. Investigation of the time course of these changes and their temporal relationship will help to determine how $\mathrm{A} \beta$ accumulation leads to synapse dysfunction and eventual loss. Synaptic ultrastructure has been examined in $\mathrm{AD}$ patients and mouse models. The consistent finding is a significant reduction of synapse density with concomitant increase in the average length of synaptic contacts as a compensatory response to synapse loss (Scheff and Price, 2006). Two aspects of synaptic functions - basal synaptic efficacy and long-term potentiation (LTP) - have been frequently examined in many studies of $\mathrm{AD}$ transgenic mice. For example, many studies have shown the reduction of basal transmission and LTP at hippocampal CA3-CA1 synapses of these transgenic mice (Larson et al., 1999; Selkoe, 2002; Oddo et al., 2003; Jacobsen et al., 2006), although other studies failed to observe either or both of these functional changes in vivo or in brain slices (Chapman et al., 1999; Hsia et al., 1999; Fitzjohn 
et al., 2001; Jolas et al., 2002; Gureviciene et al., 2004; Zhang et al., 2005). However, the nature and progression of synaptic changes that lead to synapse dysfunction and loss remain to be fully characterized.

Drosophila has been used extensively to express neurodegeneration-causing proteins or peptides for the study of human neurodegenerative diseases, including polyglutamine expansionrelated diseases and Parkinson's disease, and has provided valuable insights into the distinct cellular and molecular mechanisms underlying these diseases (Bilen and Bonini, 2005; Cauchi and van den Heuvel, 2006; Marsh and Thompson, 2006). Drosophila $\mathrm{AD}$ models were generated by expression of human A $\beta$ or APP/ presenilin/BACE ( $\beta$-secretase activity of the $\beta$-site APP-cleaving enzyme). These $\mathrm{AD}$ flies exhibited age-dependent $\mathrm{AD}$-like pathology and behavioral changes (Finelli et al., 2004; Greeve et al., 2004; Crowther et al., 2005; Iijima-Ando et al., 2008).

In the present study, we performed extensive time course analysis of the function and structure of both axon and presynaptic terminals at the identified single-neuron level in adult flies with a small group of neurons expressing $A \beta$. We found that $A \beta$ expression caused intracellular accumulation of $\mathrm{A} \beta$ and produced age-dependent depletion of presynaptic mitochondria, before a range of other presynaptic changes.

\section{Materials and Methods}

\section{Genetics and stocks}

Drosophila stocks were cultured on standard medium at $23-25^{\circ} \mathrm{C}$. After pupation, the adult flies were cultured on standard medium and entrained into a $12 \mathrm{~h}$ light/dark cycle at $28.5^{\circ} \mathrm{C}$ if not otherwise indicated. The control (Cantonese S) and $w^{1118}$ were used as controls. The upstream activating sequence (UAS) transgenic lines used for expressing wild-type $\mathrm{A} \beta_{1-42}, \mathrm{~A} \beta_{1-40}$, and the arctic mutant $\mathrm{A} \beta_{1-42}$ are generous gift from Dr. D. C. Crowther (Cambridge University, Cambridge, UK) (Crowther et al., 2005), in which the recombinant $\mathrm{A} \beta$ DNAs are fused to a secretion signal of the Drosophila necrotic gene. The P[Gal4]A307 (Allen et al., 1999) was used to drive the expression of $\mathrm{A} \beta$ in the giant fiber (GF) system and other components of the nervous system, and $\mathrm{P}[$ Gal4-elav.L $] 3$ was used for pan-neuronal expression. P $\{$ UAS-mitoGFP.AP 3 (Drosophila Bloomington Stock Center, University of Indiana, Bloomington, IN) was used to label mitochondria.

\section{Behavioral assays}

The flight assay was performed according to a previous study (Fayyazuddin et al., 2006). Briefly, single flies were tapped down into a glass cylinder with inner diameter of $100 \mathrm{~mm}$ and length of $390 \mathrm{~mm}$, which was divided into 13 zones of $30 \mathrm{~mm}$ each. The zone in which the fly landed was noted for each fly and used to estimate the landing height. At least 10 flies were used for each genotype at each age, and the results were averaged. In some cases, aged flies failed to fly at all and dropped into the bottom of the cylinder, and the landing height was taken as " 0. "

\section{Longevity assay}

One hundred flies from each genotype were equally separated into five vials containing standard fly food and dry yeast and were cultured at $28.5^{\circ} \mathrm{C}$. After every $3 \mathrm{~d}$, flies were transferred into vials with fresh food and dried yeast, and dead flies were counted. Survival rates were analyzed with the SPSS 11 Kaplan-Meier software.

\section{Electrophysiology}

We recorded both excitatory junctional potential (EJP) and current (EJC) in the giant fiber system as described previously with some modifications (Huang et al., 2006). Briefly, during EJP recording, an adult female fly at a certain age was mounted ventral-side down on a glass with Tackiwax (Boekel Scientific) soft wax under a dissection microscope. The fly legs and wings were all removed to prevent disturbance while the stimulation was given. A glass reference electrode was inserted into the abdomen, and a glass stimulating electrode was inserted into each eye. A glass recording electrode was driven through the dorsal thorax cuticle. During high-frequency stimulation, the stimulation intensity was $5-20 \mathrm{~V}$ with the duration of $0.2 \mathrm{~ms}, \sim 150 \%$ of the threshold stimulation intensity at $0.5 \mathrm{~Hz}$. Intracellular penetration into the muscle was monitored by a sudden potential drop of $40-70 \mathrm{mV}$. The muscle identity [dorsal longitudinal muscle (DLM) vs tergotrochanteral muscle (TTM)] was determined by electrode placement and verified by the latency of evoked EJP. Signals were amplified by Multiple Clamp 700B (Molecular Devices) and digitized at $20 \mathrm{kHz}$ by Digidata 1440A (Molecular Devices). Data were collected and analyzed with pClamp software (version 10.0; Molecular Devices). All glass electrodes were filled with $3 \mathrm{~m} \mathrm{KCl}$. The recording environment temperature was $25^{\circ} \mathrm{C}$.

During EJC recording, an adult female fly was laterally mounted over a water resistant Sylgard bar, secured with Tackiwax, and wrapped with Parafilm, in which a hole was made for dissecting overlying cuticle and muscles to expose one set of DLM cells in $\mathrm{Ca}^{2+}$-free saline consisting of the following (in mM): $128 \mathrm{NaCl}, 2 \mathrm{KCl}, 4 \mathrm{MgCl}_{2}, 5$ HEPES, and 36 sucrose. The dissection saline was then replaced with oxygen-containing $1.8 \mathrm{mM} \mathrm{CaCl}_{2}$ saline, perfused at $0.3-0.4 \mathrm{ml} / \mathrm{min}$. The posterior dorsal mesothoracic nerve carrying the DLM motor neuron axons was sucked into a glass stimulation pipette. Two glass microelectrodes (2-10 M $\Omega$ ) filled with $3 \mathrm{M} \mathrm{KCl}$ were inserted in the e-cell or d-cell of the DLM. The DLM resting potentials ranged from -70 to $-90 \mathrm{mV}$. Two-electrode voltage clamp (TEVC) was performed using an Axoclamp 900A amplifier (Molecular Devices), with the holding potential at $-80 \mathrm{mV}$. Data were collected with Digidata 1322A (Molecular Devices) and analyzed with pClamp software (version 9.2; Molecular Devices). The decay constant $(1 / \tau)$ of EJC peak amplitudes was calculated by exponential function fitting with $y=e^{-x / \tau}+b$. The recording environment temperature is $19^{\circ} \mathrm{C}$.

\section{Electron microscopy study}

For electron microscopic (EM) investigation of the presynaptic terminals of DLM motor neurons, the thorax was isolated and dissected along the midline into two parts in cold PBS. For the investigation of the axons of DLM motor neurons, the cuticle at the ventral site of the thorax was open to facilitate the immersion of fixative into the ventral ganglion in which the DLM motor neurons are located. Then, preparations were immediately fixed in $2 \%$ paraformaldehyde and $2 \%$ glutaraldehyde in $0.1 \mathrm{M}$ phosphate buffer, $\mathrm{pH} 7.4$, for $30 \mathrm{~min}$ at room temperature. Preparations were then further fixed in $4 \%$ glutaraldehyde in $0.1 \mathrm{~m}$ phosphate buffer, $\mathrm{pH} 7.4$, for $2 \mathrm{~h}$ at room temperature or overnight at $4^{\circ} \mathrm{C}$, after which the preparations were postfixed in $2 \% \mathrm{OsO}_{4}$ in the same buffer for $2 \mathrm{~h}$ at $4^{\circ} \mathrm{C}$, block stained in $1 \%$ aqueous uranyl acetate, dehydrated with increasing concentrations of ethyl alcohol, and embedded in Epon 812. LKB cut ultramicrotone or Leica EM UC 6 ultramicrotone was used to cut samples. For the study of DLM presynaptic terminals, ultrathin sections (70 $\mathrm{nm}$ ) were obtained by cutting the DLM fibers transversely. For the study of the axons of DLM motor neurons, the cutting started from the ventral side of the thorax at the step of $10 \mu \mathrm{m}$. The sections of the first $160 \mu \mathrm{m}$ were thrown away. Then the sectioning was intermittent, with a cutting followed by staining of the section from the cutting with toluidine blue and examination of the stained section under microscope until the nerve containing the axons of DLM motor neurons appear in the semithin section. Afterward, ultrathin sections were collected and double stained with uranyl acetate and lead citrate. Ultrathin sections were examined using a Jeol 1220 electron microscope at $80 \mathrm{kV}$ and Hitachi H-7650. EM pictures were taken by CCD camera and analyzed with Image-Pro Plus 6.0 software (Media Cybernetics).

\section{Immunostaining and imaging}

Whole-mount $A \beta$ staining. The whole CNS of flies, including the brain and ventral ganglion, was dissected out in PBS and fixed with $4 \%$ paraformaldehyde in PBS for $\sim 45 \mathrm{~min}$. Preparations were washed with PBS for 10-15 min and repeated twice and then treated with formic acid (70\%) for $30 \mathrm{~min}$ to reexpose the epitope, followed by three washes with PBS-Triton X-100 (0.5\%)-BSA (5\%), 2-3 h incubation with primary antibody (6E10), PBS wash, 2 h incubation with FITC-conjugated secondary antibody, and confocal imaging. Experiments were done at room temperature. 
Mito-green fluorescent protein imaging and puncta quantification. Control mito-green fluorescent protein (GFP) and $A \beta_{\text {arc }}$-mito-GFP flies were dissected in PBS to expose DLM cells and fixed with $4 \%$ paraformaldehyde in PBS for $\sim 45 \mathrm{~min}$. Preparations were then washed and mounted with Vectashield mounting media (Vector Laboratories) and imaged with a laser scanning confocal microscope (Zeiss LSM 510 META NLO) at the step of $1 \mu \mathrm{m}$ to acquire the projection of $Z$-stack images. At each stage of age, a standard image of mito-GFP puncta in a control fly was taken, and then the imaging parameters of it was used for imaging on all the rest control flies and $\mathrm{A} \beta_{\text {arc }}$ flies. The density of mito-GFP puncta was calculated with Stereo Investigator software (MBF Bioscience).

Time-lapse imaging of axonal transport of mitochondria. Flies were dissected and mounted in the same way as that in EJC recording. The dissected preparations were examined under an upright Zeiss confocal microscopy (Zeiss LSM 510 META NLO) equipped with a $63 \times$ water-immersion objective (C-Apochromat $63 \times)$ at room temperature $\left(20-23^{\circ} \mathrm{C}\right)$. An axon of DLM motor neuron was aligned horizontally across the imaging region, and a 50 $\mu \mathrm{m}$ segment of the axon was selected to be photobleached to eliminate the strong fluorescence of the stationary GFP-labeled mitochondria clusters. The pinhole was set to maximum to get the maximal depth of imaging $(10 \mu \mathrm{m})$. Time-lapse images were acquired at a rate of $5 \mathrm{~s}$ within $60 \mathrm{~min}$ after dissection.

\section{Statistical analysis}

Student's $t$ test, unpaired and two-tailed, was used for significance analysis. Data were represented as mean \pm SEM.

\section{Results}

$\mathrm{A} \boldsymbol{\beta}$ accumulates intracellularly and induces age-dependent behavioral changes

The flight behavior of Drosophila is controlled by the GF system, which consists of a pair of giant fiber neurons. Each sends one giant axon to the thorax to activate different muscle fibers via two pathways: the "monosynaptic" TTM pathway via an electrical synapse and the disynaptic DLM pathway mediated by a peripherally synapsing interneuron (PSI) and its cholinergic synapse (Fig. $1 A$ ). We expressed the wild-type $A \beta$ or its arctic form (E22G), which is known to exhibit increased ability to aggregate (Nilsberth et al., 2001), in neurons of the GF system and a subgroup of neurons elsewhere in the adult Drosophila brain using the galactosidase- 4 (Gal4)-UAS method. Four groups of $\mathrm{A} \beta$ flies were generated: $\mathrm{A} \beta_{42 \times 2}, \mathrm{~A} \beta_{42 \times 1}, \mathrm{~A} \beta_{40 \times 1}$, and $\mathrm{A} \beta_{\text {arc }}$, expressing two and one copy of wild-type $A \beta_{1-42}$, one copy of $A \beta_{1-40}$, and one copy of the arctic form of $\mathrm{A} \beta_{1-42}$, respectively. Pan-neuronal expression of either wild-type or the arctic form of $A \beta_{1-42}$ produced intracellular accumulation of $\mathrm{A} \beta$, accelerated age-dependent decline of mobility, and shortened the fly's lifespan (Crowther et al., 2005). Consistent with this finding, we found that expression of both wild-type and the arctic form of $\mathrm{A} \beta_{1-42}$ resulted in the accumulation in the soma and axon, as shown by immunostaining with antibody against $\mathrm{A} \beta_{1-17}$ (Fig. $1 B$ ). Behavioral analysis revealed
B
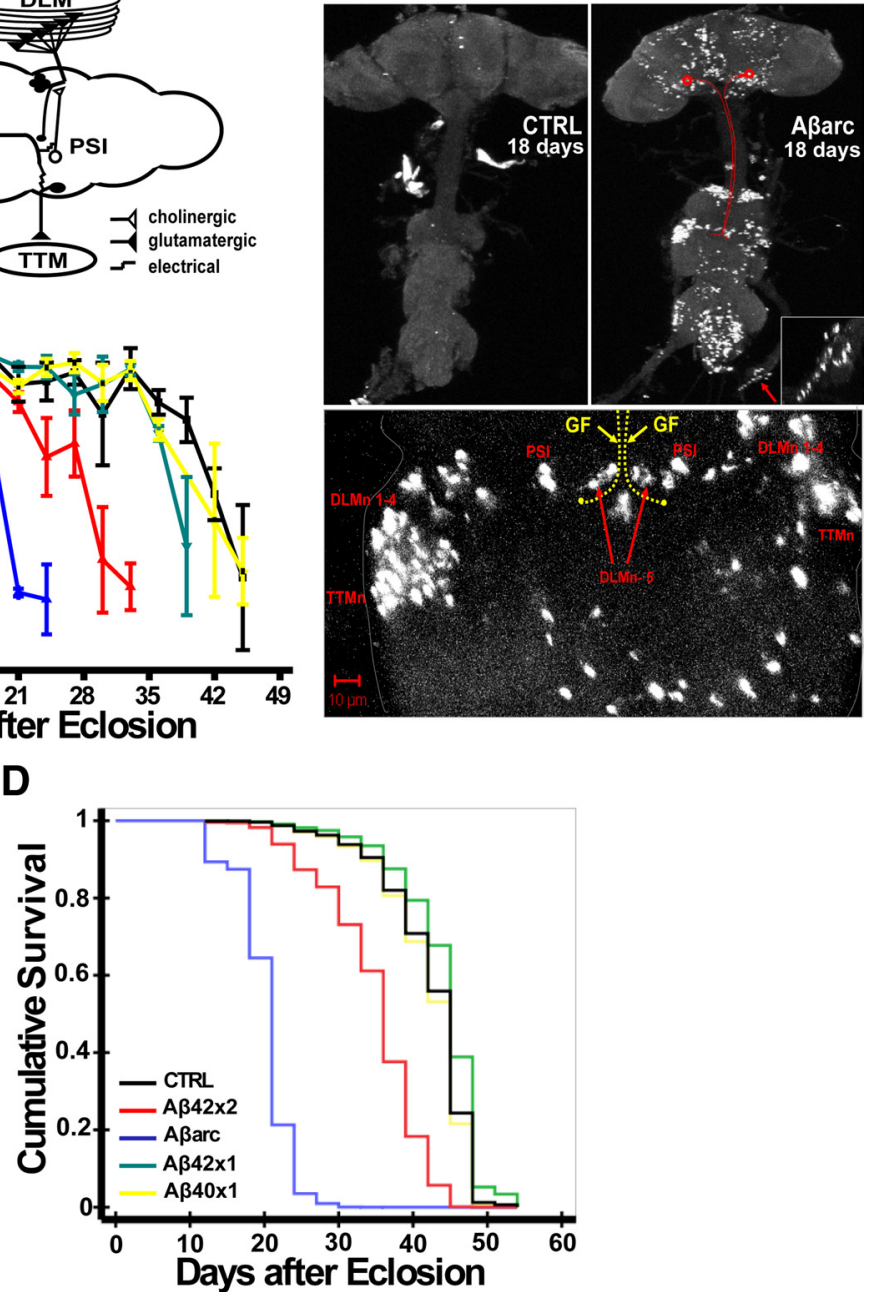

Figure 1. $A \beta$ accumulates in the cell body and axon of neurons in the giant fiber system and causes age-dependent decline of flight ability and early death. $\boldsymbol{A}, A$ diagram of the GF system. Only half of the giant fiber system is drawn for clarity. $\boldsymbol{B}$, Immunoand $A \beta_{\text {arc }}$ are [Gal4]A307; [UAS]A $\beta_{42 \times 2}$, [Gal4]A307; [UAS]A $\beta_{42 \times 1},\left[\right.$ Gal4]A307; [UAS]A $\beta_{40 \times 1}$, and [Gal4]A307; [UAS]A $\beta_{\text {arc }}$ respectively. $n \geq 30$ flies for each data point. $D$, Quantification of survival rate against age. $n=100$ flies for each genotype.

that $\mathrm{A} \beta$ expression accelerated age-dependent decline of the flight ability and shortened the lifespan (Fig. 1C,D). The decline occurred first in flies expressing $A \beta_{\text {arc }}$, followed in order by those expressing $\mathrm{A} \beta_{42 \times 2}, \mathrm{~A} \beta_{42 \times 1}$, and $\mathrm{A} \beta_{40 \times 1}$ (Fig. $1 C$ ), with the order correlated with the aggregative abilities of these peptides found in vitro (Murakami et al., 2002). These results indicate that $\mathrm{A} \beta$ expression in a subgroup of Drosophila neurons had produced significant behavioral defects. The specificity of the effect of $A \beta_{1-42}$ expression was shown by the finding that the flight ability of $\mathrm{A} \beta_{40 \times 1}$ flies was similar to that of control flies harboring only two $\mathrm{A} \beta_{1-42}$ transgenes or only the Gal4 driver.

\section{$\mathrm{A} \boldsymbol{\beta}$ expression causes age-dependent transmission failure}

To investigate more directly $\mathrm{A} \beta$-induced neuronal changes, we first examined the neural transmission through the GF system in vivo. Repetitive brain stimulation at 10 or $100 \mathrm{~Hz}$ (total of 50 stimuli) was used to activate the GF system, and evoked EJPs were intracellularly recorded in DLM or in both DLM and TTM muscle fibers. In control young flies (3-7 d), EJPs were reliably elic- 
A

CTRL

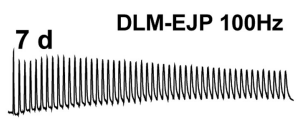

$14 \mathrm{~d}$

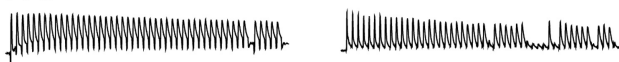

$28 d$

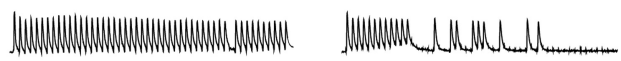

35 d

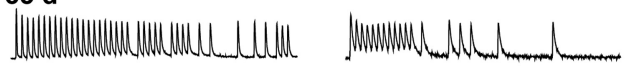

D

Brain sti.

$A \beta$ arc 14days

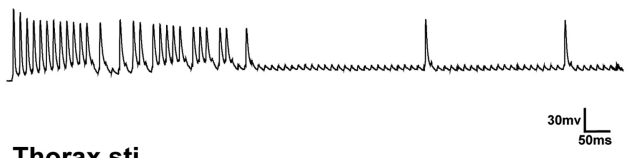

Thorax sti.

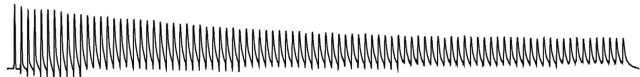

B

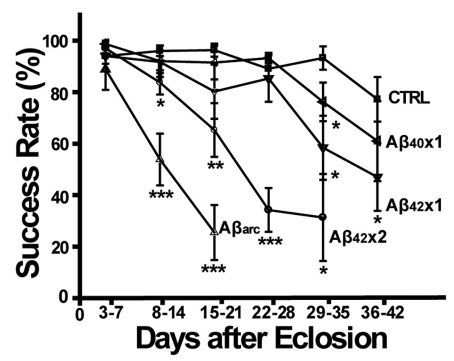

C

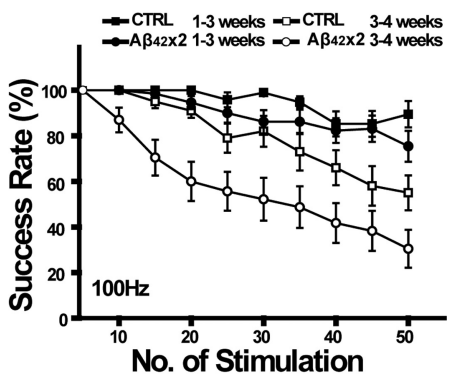

Figure 2. $\mathrm{A} \beta$ expression increases age-dependent neurotransmission failure in the disynaptic DLM pathway. $\boldsymbol{A}$, Representative $100 \mathrm{~Hz}$ brain stimulation-evoked DLM EJP recordings from control (CTRL) (left column) and $A \beta_{42 \times 2}$ (right column) flies at different ages. $\boldsymbol{B}$, The percentage of successful DLM responses to $100 \mathrm{~Hz}$ brain stimulation against age in control and $A \beta$-expressing flies. $n \geq 5$ flies for each data point. $C$, The percentage of successful responses against the sequential number of stimulus in the titanic brain stimulation ( $100 \mathrm{~Hz}, 50$ stimuli). Each data point represents the average of at least five $A \beta_{42 \times 2}$ flies. D, Brain and thorax $100 \mathrm{~Hz}$ stimulation-evoked DLM EJP recordings from a 14- $d$-old $A \beta_{\text {arc }}$ fly. Note that neurotransmission failure in brain stimulation-evoked EJP recording but not in thorax stimulation-evoked EJP recording. ${ }^{*} p<0.05,{ }^{* *} p<0.01$, and *** $p<0.001$, respectively.

A
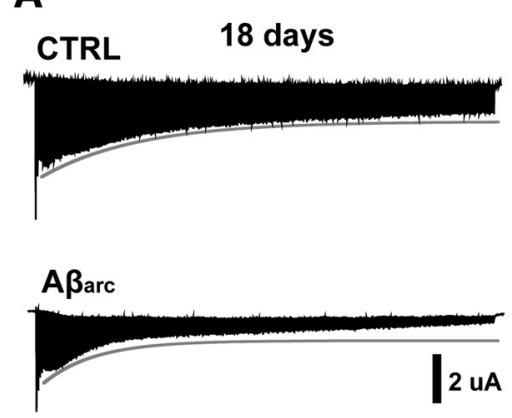

\section{Scaled}

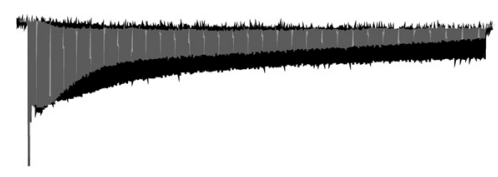

B
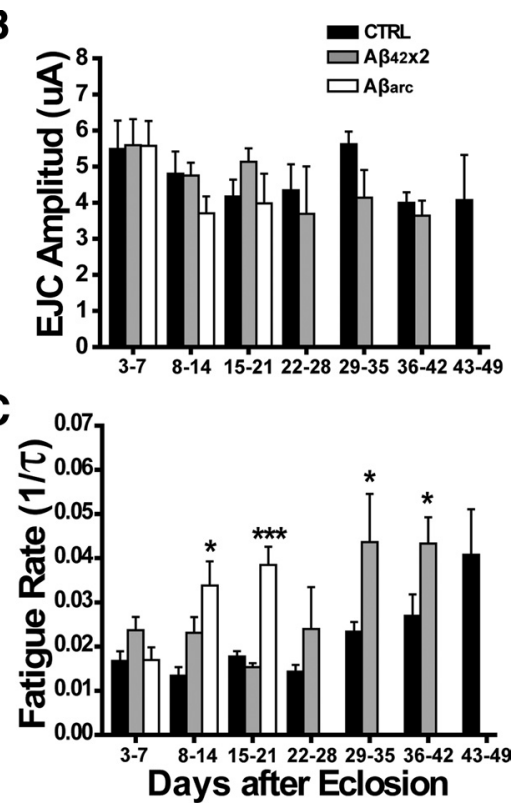

Figure 3. $A \beta$ expression enhances synaptic transmission fatigue. $A$, Representative compressed recording traces of DLM EJCS from control (CTRL) (top) and $A \beta_{\text {arc }}$ flies at age of $18 \mathrm{~d}$ (middle). The gray curved line on each trace is the fitting curve for the peak points of EJCs 8-250. In the bottom row, the $A \beta_{\text {arc }}$ EJC trace was scaled to and superimposed on the control EJC trace. $B, C$, The plots of the first EJC peak amplitude $(\boldsymbol{B})$ and fatigue rate (inverse of the decay constant $\tau$ of EJC peak amplitudes) ( $\boldsymbol{C}$ ) against age. $n \geq$ 5 flies for each data point. ${ }^{*} p<0.05$ and ${ }^{* * *} p<0.001$, respectively.

ited by each stimulus at a low stimulus frequency of $10 \mathrm{~Hz}$ (success rate of $100 \%$ ) (supplemental Fig. $1 \mathrm{~A}$, available at www. jneurosci.org as supplemental material) for either the DLM or TTM pathway. Occasional failure of eliciting EJPs appeared during high-frequency stimulation (50 stimuli at $100 \mathrm{~Hz})$ in the disynaptic DLM pathway (Fig. $2 A, B$ ), and the average success rate of neurotransmission declined slightly with age during the subsequent weeks (Fig. $2 A, B$ ). In flies expressing various forms of $\mathrm{A} \beta$, however, the success rates of neurotransmission along the DLM pathway declined much more rapidly with age, with the rate of decline in the order of $\mathrm{A} \beta_{\text {arc }}>\mathrm{A} \beta_{42 \times 2}>\mathrm{A} \beta_{42 \times 1}>$ $\mathrm{A} \beta_{40 \times 1}$ (Fig. $2 B$ ). Furthermore, the failure of neurotransmission increased with time during the period of $100 \mathrm{~Hz}$ stimulation in both control and $A \beta_{42 \times 2}$ flies of different ages, with the $\mathrm{A} \beta_{42 \times 2}$ flies exhibiting more rapid decline (Fig. $2 C$ ). Similar findings were found for $A \beta_{\text {arc }}$-expressing flies (data not shown). The synaptic failure under $10 \mathrm{~Hz}$ stimulation was slightly different between aged control and $\mathrm{A} \beta_{42 \times 2} / \mathrm{A} \beta_{\text {arc }}$ flies (supplemental Fig. $1 A$,

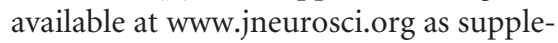
mental material). This indicates that $A \beta$ expression resulted in a higher susceptibility to use-dependent synaptic failure, presumably attributable to presynaptic fatigue during high-frequency transmission.

In addition to the DLM pathway, we also examined neurotransmission in the "monosynaptic" TTM pathway in control and $\mathrm{A} \beta$ flies of different ages. In general, success rate of transmission in the TTM pathway was much higher than that of the DLM pathway, with EJPs rather faithfully evoked by $100 \mathrm{~Hz}$ stimulation in all young flies, and the success rate of transmission showed a similar small decline in aged (>3 weeks) control and $A \beta_{42 \times 2}$-expressing flies (supplemental Fig. $1 B-D$, available at www.jneurosci.org as supplemental material). The lower sensitivity of monosynaptic TTM than disynaptic DLM pathway to $A \beta$ disruption suggests that the main effect of neurotransmission failure in $A \beta$ flies was a result of disruption of central synapse between the PSI and motor neurons (Fig. 1A). This is further supported by the finding that the transmission failure along the DLM pathway was characterized by the sudden disappearance of EJPs that is consistent with the failure of synaptic transmission between PSI and the motor axon, which is mediated by axo-axonal cholinergic synapse (Ikeda et al., 1980; King and Wyman, 1980). Furthermore, in six $\mathrm{A} \beta_{\mathrm{arc}}$ flies 
(8-20 d), direct stimulation of motor axons innervating DLM by placing the stimulating electrode in the thorax was applied after brain stimulation. As shown by example recordings in Figure $2 D$, direct stimulation of motor axons evoked 100\% successful EJP response in each fly, whereas brain stimulation induced $39 \pm$ $12 \%$ successful EJP response $(p<0.01)$. Together, these findings indicate that $\mathrm{A} \beta$ expression induces an age-dependent synaptic defect at a central synapse, resulting in neurotransmission failure in the GF system.

$\mathrm{A} \beta$ expressed in our flies was fused to a secretary signaling peptide; a portion of $A \beta$ should have been secreted out of neurons, although $A \beta$ expression resulted in predominantly intracellular accumulation. To investigate whether the induced neurotransmission failure was mainly a result of extracellular $\mathrm{A} \beta$, we compared the decline rate of neurotransmission along the DLM pathway in flies with $\mathrm{A} \beta$ expression driven by $\mathrm{P}[\mathrm{Gal} 4 \mathrm{~A} 307$ with that in flies with $\mathrm{A} \beta$ expression driven by $\mathrm{P}[$ Gal4-elav.L]3. $\mathrm{P}[$ Gal4-elav.L $] 3$ is a pan-neuronal expression driver that presumably should have produced more extracellular $\mathrm{A} \beta$. In addition, to promote more $\mathrm{A} \beta$ being targeted to plasma membrane and secreted out to extracellular space, we cultured flies at $23.5^{\circ} \mathrm{C}$ rather than $28.5^{\circ} \mathrm{C}$. The decline rate of neurotransmission in flies with arctic $\mathrm{A} \beta$ expression driven by $\mathrm{P}[\mathrm{Gal} 4] \mathrm{A} 307$ was faster than that in flies with arctic $\mathrm{A} \beta$ expression driven by P[Gal4-elav.L]3 (supplemental Fig. 5, available at www.jneurosci.org as supplemental material). This result does not support that the induced transmission failure was mainly attributable to extracellular $A \beta$.

\section{$\mathrm{A} \boldsymbol{\beta}$ expression causes age-dependent presynaptic defects}

Our finding that $\mathrm{A} \beta$ accumulates in DLM motor neurons as well as PSI neurons is consistent with the observation that both cholinergic and glutamatergic synapses were affected in AD brains. To further investigate the synaptic function of DLM neuromuscular synapses, we performed TEVC recording of EJCs in the DLM fibers, in response to electrical stimulation of motor axons at 10 or $100 \mathrm{~Hz}$. A train of $100 \mathrm{~Hz}$ stimuli (250 pulses, $0.4 \mathrm{~ms}$ in width) induced EJCs that exhibited a progressive decay in the peak amplitude with time, indicating synaptic fatigue in response to highfrequency use. As shown by example recordings in Figure $3 A$, we found that 18 -d-old control fly exhibited a slower rate of synaptic fatigue than that of $\mathrm{A} \beta_{42 \times 2}$ fly of the same age. The rate of synaptic fatigue was quantified by the inverse of decay constant $\tau$ of the peak EJC amplitude (see Materials and Methods) and the ratio of the amplitudes of the 100th EJC to the first EJC (supplemental Fig. 2, available at www.jneurosci.org as supplemental
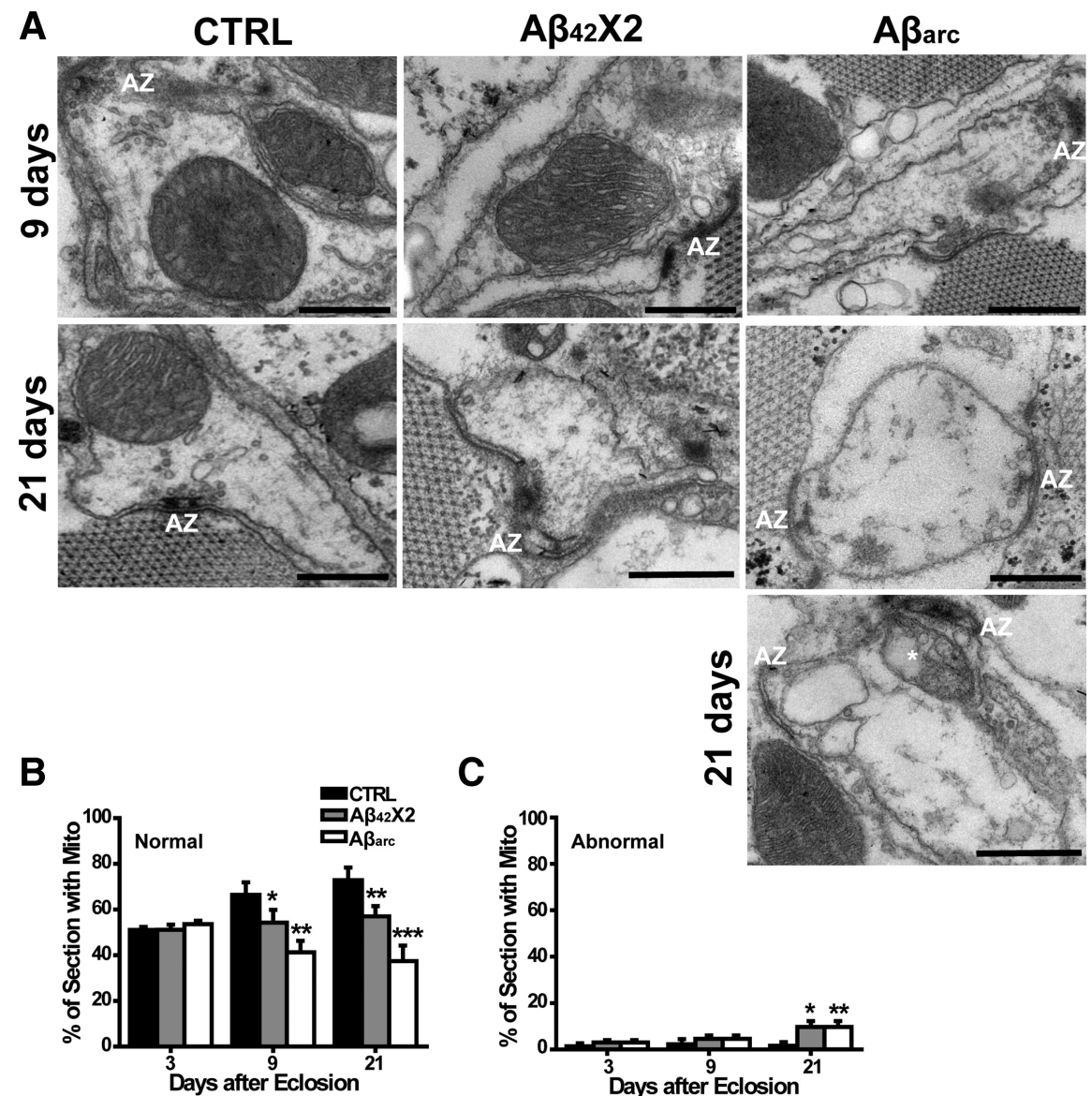

C
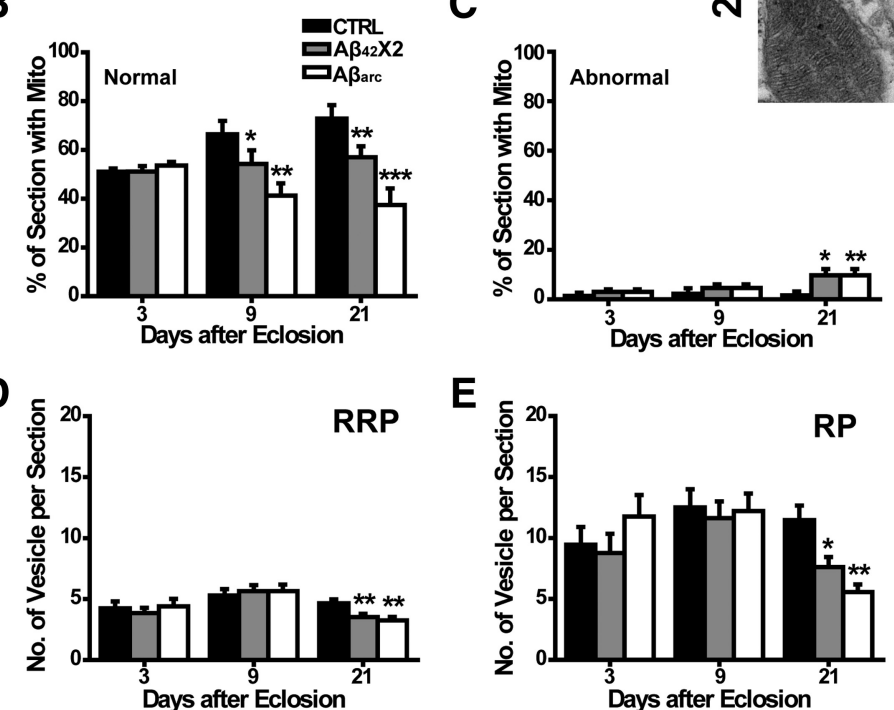

Figure 4. $A \beta$ expression causes age-dependent depletion of presynaptic mitochondria and synaptic vesicles. $\boldsymbol{A}$, Representative EM pictures of DLM motor neuron-DLM presynaptic sections from control (left), $A \beta_{42 \times 2}$ (middle), and $A \beta_{\text {arc }}$ (right) flies at age of $9 \mathrm{~d}$ (top) and $21 \mathrm{~d}$ (middle and bottom). Note the reduced synaptic vesicles in the $A \beta_{42 \times 2}$ and flies at the age of $21 \mathrm{~d}$. * indicates vacuole in mitochondria. mit, Mitochondria; AZ, active zone. Scale bar, $500 \mathrm{~nm}$. $\boldsymbol{B}$, Percentage of presynaptic sections with AZ $(\mathrm{RP})(\boldsymbol{E})$. Each data point represents the data of $40-138$ presynaptic sections from $5-10$ flies. ${ }^{*} p<0.05,{ }^{* *} p<0.01$, and ${ }^{* * *} p<0.001$, respectively.

material). Whereas the peak amplitude of the first EJC evoked by the stimulus showed a slight reduction with age in all flies (Fig. $3 B)$, the increased rate of fatigue with age appeared much earlier in $\mathrm{A} \beta_{42 \times 2}$ and $\mathrm{A} \beta_{\mathrm{arc}}$ flies than control flies (Fig. $3 C$ ), with the severity in the order of $\mathrm{A} \beta_{\text {arc }}>\mathrm{A} \beta_{42 \times 2}>$ control flies. We noted that the increased synaptic fatigue appeared during the second and fourth week in $\mathrm{A} \beta_{\text {arc }}$ and $\mathrm{A} \beta_{42 \times 2}$ flies, respectively, at $\sim 1$ week before the marked reduction in the survival rate (Fig. $1 E$ ). In contrast to that found for $100 \mathrm{~Hz}$ stimulation, synaptic fatigue was much lower during $10 \mathrm{~Hz}$ stimulation, and the agedependent changes in the fatigue rate were not significantly different between control and $\mathrm{A} \beta$ flies (supplemental Fig. 3, available at www.jneurosci.org as supplemental material). Thus, 

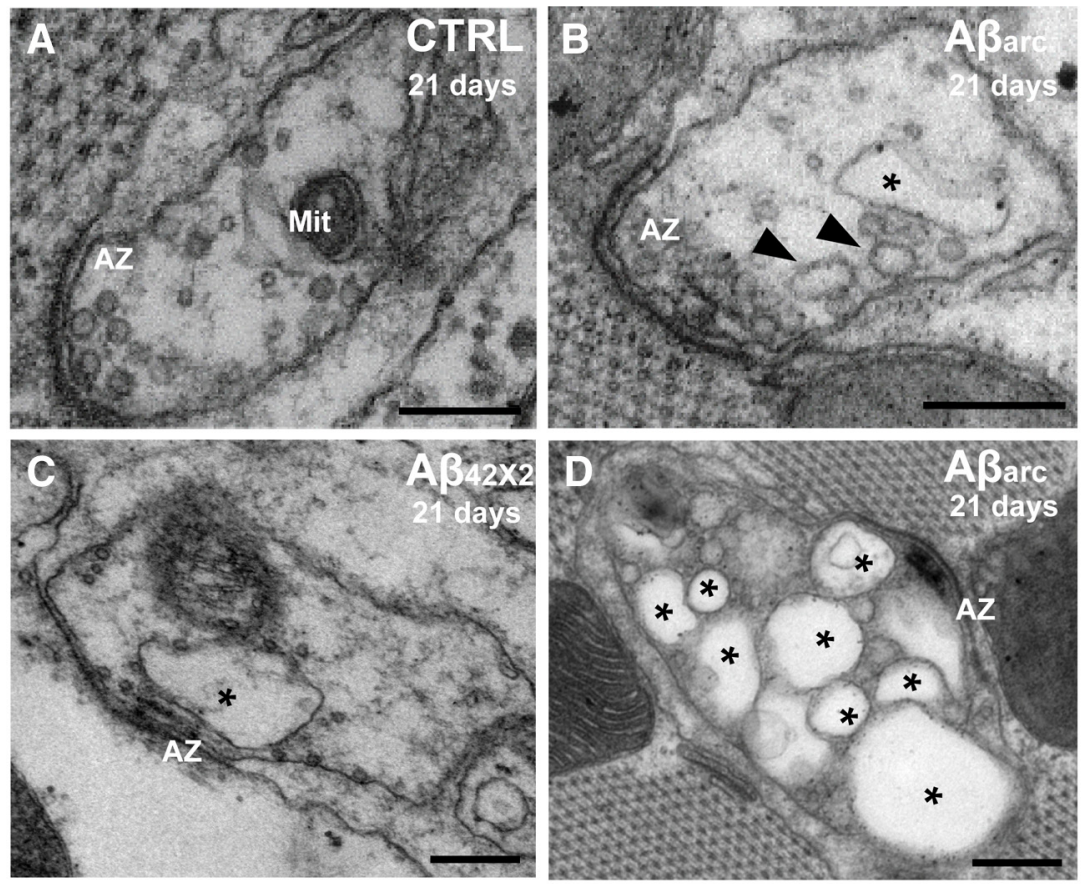

E

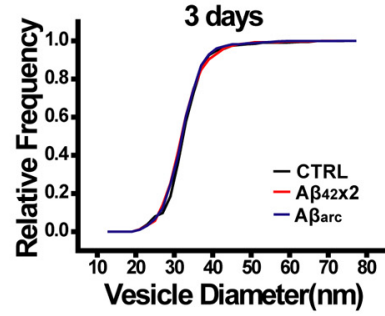

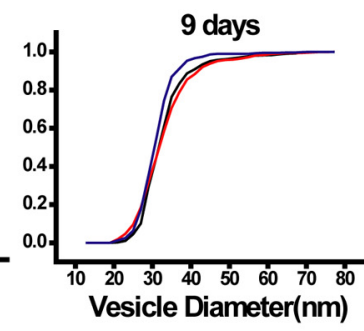

9 days

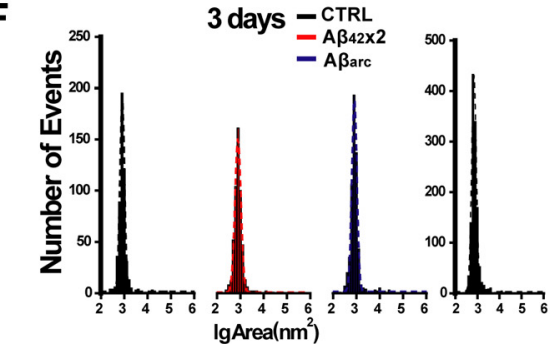

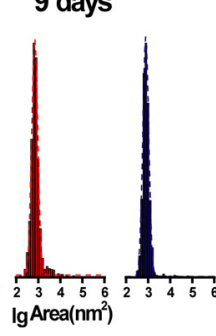

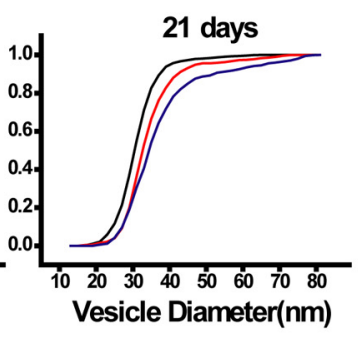

21 days

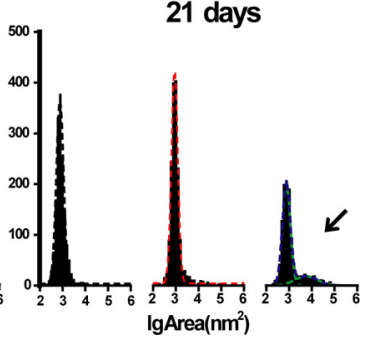

Figure 5. $A \beta$ expression increases the size and heterogeneity of synaptic vesicles and causes accumulation of presynaptic vacuoles in an age-dependent manner. Presynaptic sections from control $(\boldsymbol{A}), A \beta_{42 \times 2}(\boldsymbol{C})$, and $A \beta_{\text {arc }}(\boldsymbol{B}, \boldsymbol{D})$ flies at the age of $21 \mathrm{~d}$. The black arrowhead indicates the large synaptic vesicles, and * indicates the vacuole (diameter of $>80 \mathrm{~nm}$ ). $\boldsymbol{E}$, Quantification and accumulative probability of synaptic vesicle diameters at the age of 3,9 , and $21 \mathrm{~d}$. $n=600-800$. $\boldsymbol{F}$, The histogram of log value of the area of vesicles and vacuoles in square nanomolar. Note the second peak (indicated by arrow) in $A \beta_{\text {arc }}$ flies at the age of $21 \mathrm{~d}$. Scale bars, $200 \mathrm{~nm}$.
$4 A, B)$. Two groups of SVs were defined: the readily releasable pool (RRP) located within $150 \mathrm{~nm}$ from the active zone, and the reserve pool (RP) located beyond 150 $\mathrm{nm}$ from the active zone. We measured the frequency of the presence of mitochondria, the pool size of RP and RRP, and the size distribution of SVs in the presynaptic sections on the DLM fibers, which were identified by the presence of the active zone (Fig. $4 A$ ). We found that, in $3 \mathrm{~d}$ young flies, all these parameters were not significantly different between control flies and $A \beta_{42 \times 2}$ or $A \beta_{\text {arc }}$ flies, suggesting no early developmental defects caused by $\mathrm{A} \beta$ expression (Figs. $4 B-E, 5 C$ ). By $9 \mathrm{~d}$, there was a significant reduction in the frequency of mitochondria found in the presynaptic sections of both $\mathrm{A} \beta_{42 \times 2}$ and $\mathrm{A} \beta_{\text {arc }}$ flies (Fig. $4 C$ ), without detectable change in synaptic vesicles (Figs. $4 B$, $5 C)$. Interestingly, the reduction of presynaptic mitochondria occurred before the marked increase in synaptic fatigue, as observed during $100 \mathrm{~Hz}$ stimulation of these NMJs in both $A \beta_{42 \times 2}$ and $A \beta_{\text {arc }}$ flies (Fig. 3). By $21 \mathrm{~d}$, the mitochondria number in both $\mathrm{A} \beta_{\text {arc }}$ and $\mathrm{A} \beta_{42 \times 2}$ flies showed an additional decline (Fig. $4 B$ ). The number of abnormal mitochondria with vacuoles or broken cristae was slightly but significantly increased in both $\mathrm{A} \beta_{42 \times 2}$ and $\mathrm{A} \beta_{\text {arc }}$ flies (Fig. $4 C$ ). In addition, both the pool size of RP and RRP was significantly reduced in $\mathrm{A} \beta_{\mathrm{arc}}$ and $\mathrm{A} \beta_{42 \times 2}$ flies (Fig. $4 D, E$ ). Moreover, synaptic vesicles became more heterogeneous and significantly increased in size by $21 \mathrm{~d}$ (Fig. $5 A-E)$. Interestingly, vacuoles are present in presynaptic sections of $\mathrm{A} \beta_{42 \times 2}$ and $\mathrm{A} \beta_{\text {arc }}$ flies (Fig. $5 B-D, F$ ). However, the size of mitochondria as well as the presynaptic terminal in the three groups of flies, as estimated by their average area in the section, was not significantly different at any one of the three ages (supplemental Fig. 4, available at www.jneurosci.org as supplemental material). presynaptic synaptic defect caused by $\mathrm{A} \beta$ expression at these neuromuscular junctions appears only during high-frequency synaptic use. The defects of glutamatergic neuromuscular transmission is consistent with that found at PSI-motor axon synapses, although the presynaptic defect at the latter was revealed by the failure of evoked action potential in the motor axon.

\section{A $\beta$ expression induces age-dependent presynaptic structural changes}

Structural changes that may account for the presynaptic dysfunction at DLM neuromuscular junctions were further studied by using EM. We examined presynaptic organelles, including mitochondria and synaptic vesicles (SVs) (diameter of 25-80 $\mathrm{nm}$ ) in control, $\mathrm{A} \beta_{42 \times 2}$, and $\mathrm{A} \beta_{\operatorname{arc} \times 1}$ flies of different ages (Fig.

\section{GFP labeling of presynaptic mitochondria}

To confirm the loss of presynaptic mitochondria caused by neuronal $\mathrm{A} \beta$ expression, we expressed in the giant fiber system of control and $\mathrm{A} \beta_{\text {arc }}$ flies a construct encoding a mito-GFP fusion protein, which is specifically targeted to mitochondria (Pilling et al., 2006). The mito-GFP puncta in DLM motor nerve terminals and preterminal regions in both $\mathrm{A} \beta_{\mathrm{arc}}$ and control flies were imaged with confocal microscopy at different ages (Fig. 6A). At each age, the density of mito-GFP puncta in $\mathrm{A} \beta_{\operatorname{arc} \times 1}$ flies was determined and normalized to that observed in control flies of the same age. We found that, consistent with the age-dependent depletion of presynaptic mitochondria in the EM study (Fig. 4), the DLM motor nerve terminals and preterminal regions in $\mathrm{A} \beta_{\text {arc }}$ flies exhibited an age-dependent reduction in the density of mito- 
GFP puncta (Fig. $6 A, B$ ), with significant reduction of mito-GFP density in $\mathrm{A} \beta_{\text {arc }}$ flies observed at the age of $9 \mathrm{~d}$.

\section{$\mathrm{A} \boldsymbol{\beta}$ expression reduces} axonal mitochondria

To test whether the age-dependent depletion of presynaptic mitochondria in $\mathrm{A} \beta$ flies could be attributable to an accumulation of mitochondria in the axon, we examined the cross sections of the proximal half segment of the axons of five DLM motor neurons in both control and $\mathrm{A} \beta_{\text {arc }}$ flies at age of $21 \mathrm{~d}$ with EM. As reported previously (Ikeda et al., 1980; King and Wyman, 1980), the distal axonal segment of the PSI interneuron synapses on and is surrounded by the proximal axonal segments of five DLM motor neurons; the diameters of the axons of the five DLM motor neuron are $\sim 2-5 \mu \mathrm{m}$ (Fig. $7 A$ ). We quantified the number and size of mitochondria in control $(n=8)$ and $\mathrm{A} \beta_{\text {arc }}$ $(n=7)$ flies. The size of mitochondria was estimated by the area of mitochondria in the section. From each fly, 6-20 cross sections of DLM motor neuron axon bundle were used to obtain the average of mitochondria number per axonal section and mitochondria area. The averages of each fly were used to obtain the means for the each genotype. A total of 385 axonal sections in control and 280 in $A \beta_{\text {arc }}$ flies and 3299 mitochondria in control and 1071 in $\mathrm{A} \beta_{\text {arc }}$ flies were examined. Surprisingly, we found that the mean mitochondria number was markedly reduced in $\mathrm{A} \beta_{\text {arc }}$ flies $(3.7 \pm 0.6, n=7$ vs $7.5 \pm 0.6$ in control, $n=8, p<0.001$ ), whereas the mean mitochondria area was significantly increased $\left(89527 \pm 14237 \mathrm{~nm}^{2}, n=7\right.$ vs $51774 \pm 5837 \mathrm{~nm}^{2}$ in control, $n=8, p<$ $0.05)$, as shown by example sections in Figure 7 , suggesting a defect in mitochondria fission.

\section{$A \boldsymbol{\beta}$ expression slows axonal transport of mitochondria}

Impairment of axonal transport has been implicated in neurodegenerative diseases, including $\mathrm{AD}$. To investigate whether the depletion of presynaptic and axonal mitochondria was attributable to defective axonal transport of mitochondria, we conducted live cell time-lapse imaging using confocal microscopy in dissected flies expressing mito-GFP. To highlight the motile GFP-labeled mitochondria, photobleaching was applied to a $50 \mu \mathrm{m}$ segment of DLM axon. Individual motile GFP-labeled mitochondria were identified using kymographs, and their moving velocity was quantified. As reported pre-
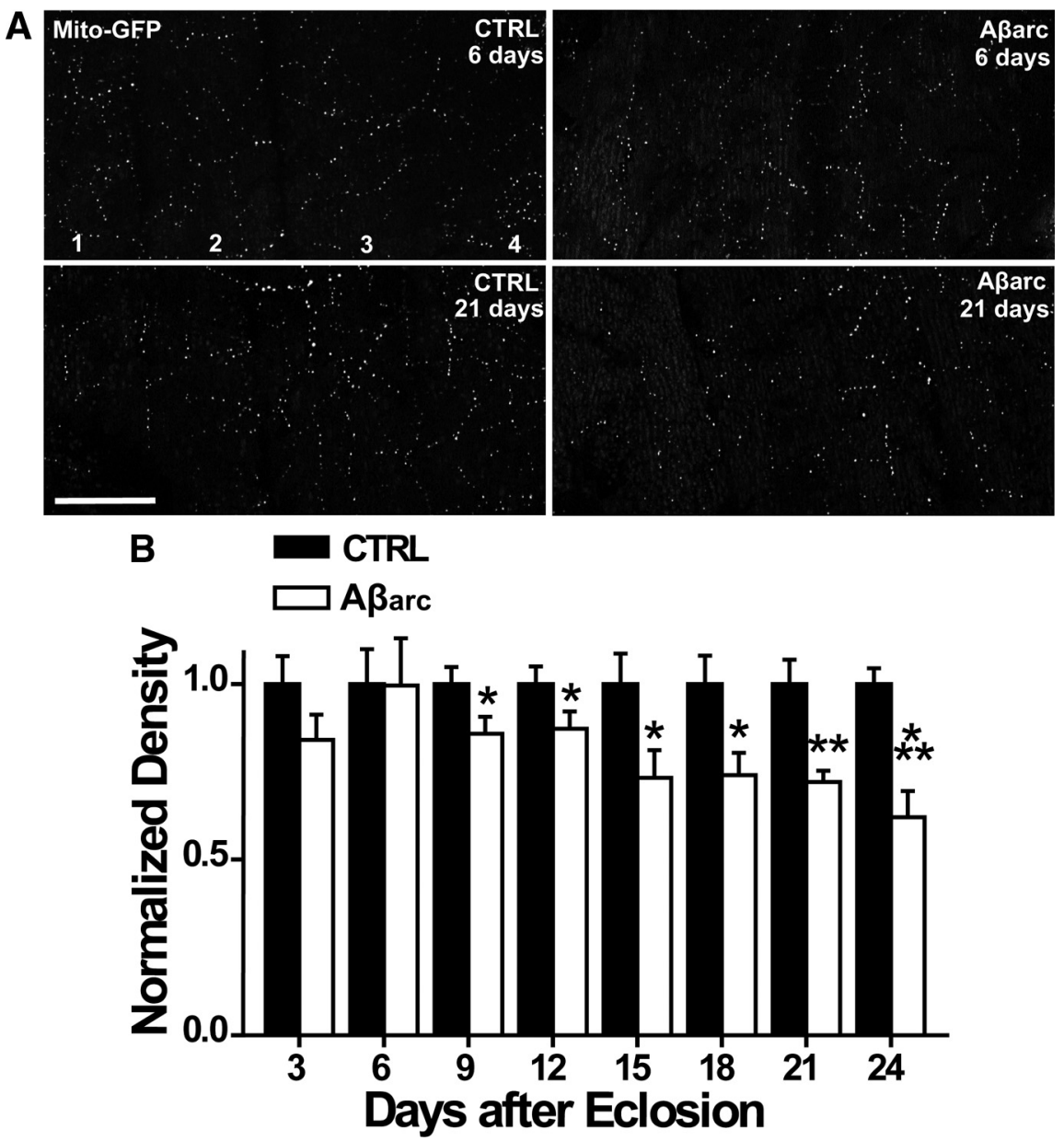

Figure 6. Quantification of GFP-labeled presynaptic mitochondria. A, Representative images of mito-GFP puncta in control and $A \beta_{\text {arc }}$ flies at the ages of 6 and $21 \mathrm{~d}$. In control flies (CTRL), only mito-GFP was expressed in the giant fiber system by using the $P[G a l 4] A 307 ;$ in $A \beta_{\text {arc }}$ flies, both $A \beta_{\text {arc }}$ and mito-GFP were expressed. The mitochondrial clusters were revealed by the mito-GFP puncta. Mito-GFP puncta in the nerve terminals and preterminal regions were collected by Z-stack imaging at the step of $1 \mu \mathrm{m}$ with a confocal microscopy. The numbers $1-4$ indicate the four DLM muscle cells. Scale bar, $50 \mu \mathrm{m}$. B, Quantification of the normalized densities of mito-GFP puncta in both control and $A \beta_{\text {arc }}$ flies at different ages. At each stage of age, a standard image of mito-GFP puncta in a control fly was taken, and the density of its mito-GFP puncta was used for normalizing the densities of mito-GFP puncta in the rest control flies and $A \beta_{\text {arc }}$ flies. The histograms represent the mean of the normalized densities at different ages. For each data point, the $n$ is between 7 and $12 .{ }^{*} p<0.05,{ }^{* *} p<0.01$, and ${ }^{* * *} p<0.001$, respectively.
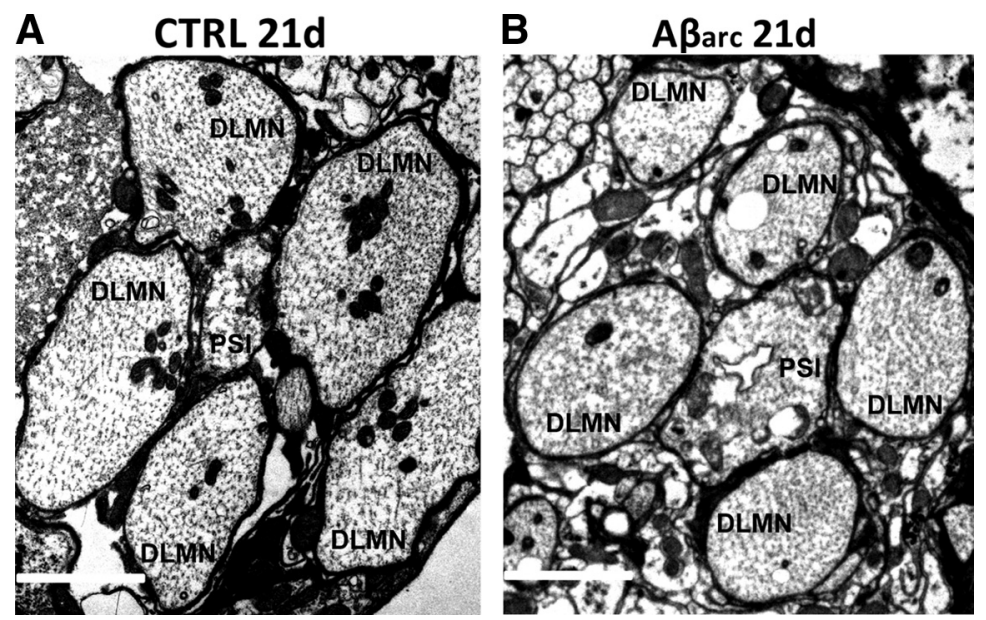

Figure 7. $A \beta$ expression reduces the number but increases the size of axonal mitochondria in aged flies. Representative cross sections of DLM motor neuron (DLMN) axons from control $(\boldsymbol{A})$ and $A \beta_{\text {arc }}(\boldsymbol{B})$ flies at the age of $21 \mathrm{~d}$. Scale bars, $2 \mu \mathrm{m}$. 
A

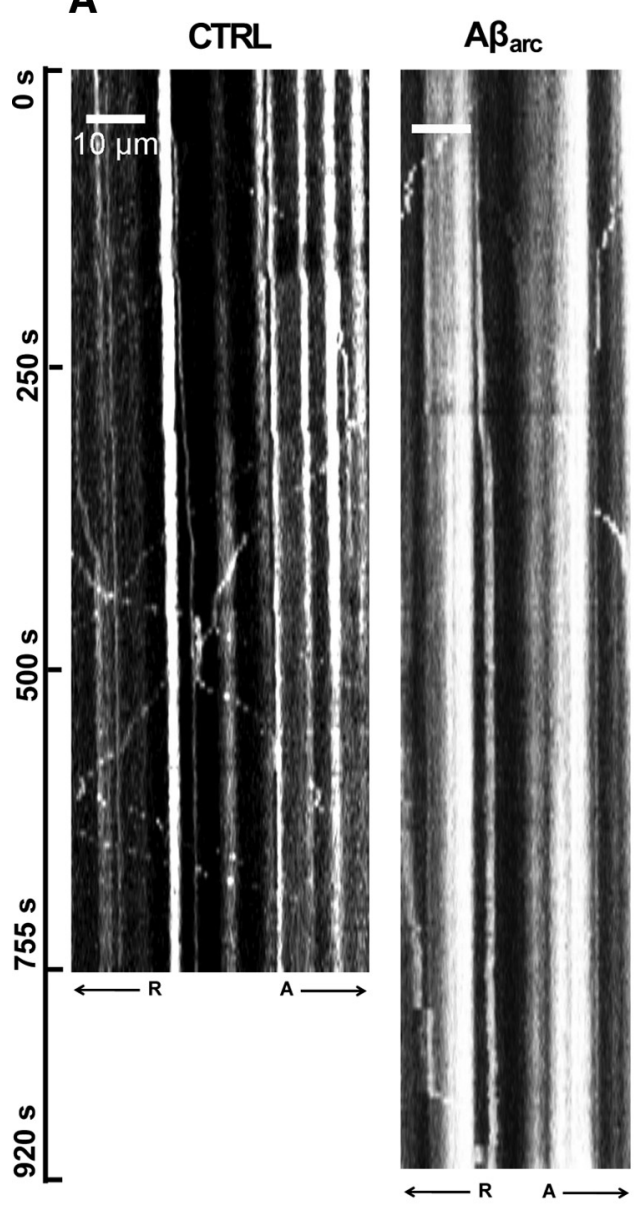

B
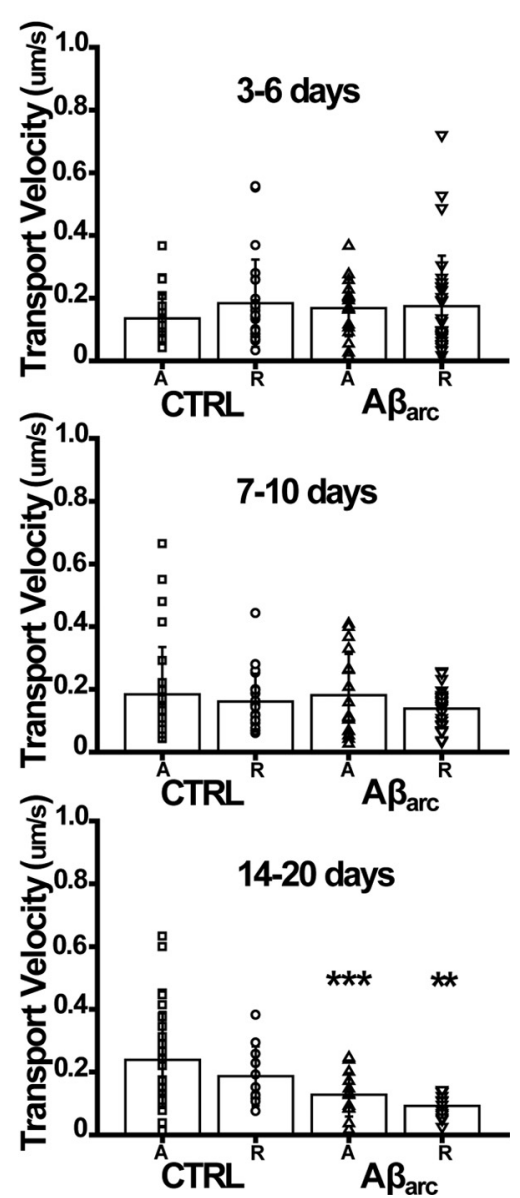

Figure 8. $A \beta$ expression causes age-dependent slow down of axonal transport of mitochondria. $A$, Kymograph showing the motility of axonal mitochondria labeled with GFP in control (CTRL) and A $\beta_{\text {arc }}$ flies at the age of $20 \mathrm{~d}$. Rand $A$ indicate retrograde and anterograde transport, respectively. Scale bars, $10 \mu \mathrm{m}$. $\boldsymbol{B}$, Quantification of the velocity of moving axonal mitochondria in control and $A \beta_{\text {arc }}$ flies at the stages of age $3-6,7-10$, and $14-20 \mathrm{~d}$. The number of flies of each genotype at each age stage is $3-5 .{ }^{* *} p<0.01$ and ${ }^{* * *} p<0.001$, respectively.

viously, those motile GFP-labeled mitochondria migrated either to or away from the soma without change in moving direction, at least in the photobleached segment and during the period of imaging (Pilling et al., 2006) (Fig. 8A). At the ages of 3-6 and $7-10 \mathrm{~d}$, the velocity of both anterograde and retrograde transport of GFP-labeled mitochondria was not different between $\mathrm{A} \beta_{\text {arc }}$ and control flies (Fig. $8 \mathrm{~B}$ ). At the age of $12-20 \mathrm{~d}$, both anterograde and retrograde transport of mitochondria in $\mathrm{A} \beta_{\text {arc }}$ flies were significantly reduced when compared with those in control flies. Interestingly, the amount of reduction was similar in both directions, $46.5 \%$ in anterograde vs $50.7 \%$ in retrograde (Fig. $8 \mathrm{~B})$, indicating no obviously imbalanced anterograde and retrograde transport of mitochondria in $\mathrm{A} \beta_{\mathrm{arc}}$ flies. Note that the reduction of transport of axonal mitochondria occurred after the depletion of presynaptic mitochondria (Fig. 4).

\section{Discussion}

By expressing A $\beta$ in the GF system in Drosophila with a tissuespecific driver, we generated an $\mathrm{AD}$ model for investigating agedependent alterations of synaptic function and ultrastructure at the identified single-neuron level. We found that $A \beta$ accumulates in the neuronal soma and axon in the GF system. $A \beta$ expression caused age-dependent reduction of flight ability and early death and a range of age-dependent functional and structural changes along the polysynaptic pathway of the GF system. Functional changes include elevated susceptibility to synaptic fatigue and transmission failure during highfrequency use and slow down of axonal transport of mitochondria. Structural changes include depletion of presynaptic and axonal mitochondria and synaptic vesicles and increase of large presynaptic vacuoles. The depletion of presynaptic mitochondria occurred before other changes. These presynaptic alterations, particularly the increased synaptic fatigue during high-frequency use, may result in reduced postsynaptic excitation and LTP in AD mice (Selkoe, 2002). Moreover, our study is consistent with the hypothesis that intracellular $\mathrm{A} \beta$ accumulation could be sufficient to initiate and propagate $\mathrm{AD}$ pathology, synaptic dysfunction in particular (Wirths et al., 2004; LaFerla et al., 2007).

$\mathrm{A} \beta$ expressed in our flies was fused to a secretary signaling peptide. Presumably, $\mathrm{A} \beta$ should have been secreted out of neurons. However, in the culture of Drosophila S2 cells transfected with the same recombinant DNA, A $\beta$ was predominantly retained within the cells with barely detectable level in the medium; particularly, the arctic mutant $\mathrm{A} \beta$ was only found in the cell lysate (Crowther et al., 2005, their Fig. $2 b$ ). When expressed in neurons of flies, $A \beta$ predominantly accumulated within neurons, at least before the death of those neurons (Crowther et al., 2005; present study). Thus, the $\mathrm{A} \beta$ expressioninduced early loss of presynaptic mitochondria in the present study might be mainly attributable to the intraneuronal $\mathrm{A} \beta$. It is unlikely mainly attributable to extracellular $\mathrm{A} \beta$ because flies expressing wild-type $\mathrm{A} \beta$, which presumably had more extracellular $\mathrm{A} \beta$, exhibited less loss of mitochondria and less severe presynaptic defect than flies expressing arctic mutant A $\beta$. Moreover, we expressed $A \beta$ in flies with a pan-neuronal driver. In those flies, which presumably had more extracellular $\mathrm{A} \beta$, the neurotransmission failure along the DLM pathway occurred later and was less severe than that in flies with $\mathrm{A} \beta$ expression driven by $\mathrm{P}[\mathrm{Gal} 4] \mathrm{A} 307$. This result further suggests that $\mathrm{A} \beta$ expression-induced loss of mitochondria and presynaptic defects were not mainly attributable to extracellular $\mathrm{A} \beta$.

Intracellular $\mathrm{A} \beta$ accumulation occurs early in $\mathrm{AD}$ patients and mice and is localized in endosomes, lysosomes, multi-vesicular body, and mitochondria (Lustbader et al., 2004; Gouras et al., 2005; Manczak et al., 2006; LaFerla et al., 2007). A $\beta$ produces multiple phenotypes by binding to proteins in mitochondria, including changes in the release of reactive oxygen species (ROS), $\mathrm{Ca}^{2+}$ buffering, cytochrome $c$ activity, and mitochondria morphology (Lustbader et al., 2004; Du et al., 2008). Eliminating these proteins or blocking their binding to $\mathrm{A} \beta$ prevents or minimizes pathological change and cognitive deficits in $\mathrm{AD}$ mice (Lustbader et al., 2004; Du et al., 2008). These findings indicate that mitochondria is a major target for $\mathrm{A} \beta$, and disruption of 
mitochondria function is a major component or mechanism of $\mathrm{AD}$ pathogenesis. Accumulation of $\mathrm{A} \beta$ at presynaptic mitochondria may disrupt synaptic function by disrupting presynaptic mitochondria function (Reddy and Beal, 2008). Our data demonstrate that $\mathrm{A} \beta$ accumulation reduces presynaptic mitochondria number, indicating that lack of mitochondria might be a major cause of $\mathrm{A} \beta$-induced presynaptic deficit.

The depletion of presynaptic mitochondria could be attributable to a reduced transport of mitochondria or to a global reduction of mitochondria in the neuron. $A \beta$ oligomerization along axonal microtubules has been found in $\mathrm{AD}$ patients and mice (Wirths et al., 2002, 2007; Takahashi et al., 2004). In our A $\beta$ flies, $\mathrm{A} \beta$ was found to be localized in the axons of presynaptic terminals with mitochondria depletion (Fig. 1B). Axonal A $\beta$ could disrupt axonal transport of mitochondria. Indeed, axonal transport of mitochondria was significantly reduced in the aged $\mathrm{A} \beta$ flies. However, the early depletion of presynaptic mitochondria in $A \beta$ flies could not be ascribed to the reduction of anterograde transport because of two reasons. The first is that the depletion of presynaptic mitochondria occurred before the change of axonal transport of mitochondria. The second is that not only the anterograde but also the retrograde transport of mitochondria was reduced in $\mathrm{A} \beta$ flies, and the ratio of the anterograde to the retrograde velocity is similar to that in control flies, indicating no unbalanced axonal transport of mitochondria. Therefore, the depletion of presynaptic mitochondria could be attributable to another reason. Each DLM motor neuron has a soma of 10-20 $\mu \mathrm{m}$, a long axonal truck of $\sim 2 \mu \mathrm{m}$ in diameter, and thousands of presynaptic terminals of 1-2 $\mu \mathrm{m}$ in diameter (Ikeda et al., 1980; Huang et al., 2006). The volume of the sum of axonal and presynaptic terminals is much bigger than the volume of the soma. Thus, the remarkable reduction of mitochondria number in the axon and presynaptic regions indicates a global depletion of mitochondria in the DLM motor neuron. In support of this, the mitochondria number in the soma of neurons in $\mathrm{AD}$ patients is also significantly reduced (Hirai et al., 2001). Global reduction of mitochondria in the neuron could be attributable to a decrease in mitochondria biogenesis or an increase of mitochondria turnover. The decrease in number and increase in size of somatic and axonal mitochondria suggest an impairment of mitochondria fission, a critical process for mitochondria biogenesis.

The size of mitochondria in the proximal axon (diameter of 2-5 $\mu \mathrm{m}$ ) of DLM motor neuron was significantly increased in aged $\mathrm{A} \beta$ flies. This is consistent with the finding in $\mathrm{AD}$ patients, in which the size of mitochondria in the soma of neurons is significantly increased (Hirai et al., 2001). However, the mitochondria size in the presynaptic terminals in $\mathrm{A} \beta$ flies at the three examined ages was not significantly changed. This might be attributable to two reasons. The first is that the size and shape of mitochondria in neurons vary widely and depend on its location in neurons, such as soma, axon, and dendrites. The second is that big mitochondria might be prevented to transport into relatively much smaller presynaptic terminals with even smaller upstream axon segment.

Mitochondria are the source of ATP and the major organelle for $\mathrm{Ca}^{2+}$ storage in the presynaptic terminal. Mitochondrial ATP is required for mobilizing SVs from the RP during intense electrical stimulation in Drosophila (Verstreken et al., 2005). In addition, the replenishment of RP SVs depends on the internal $\mathrm{Ca}^{2+}$ release (Kuromi and Kidokoro, 2002). Thus, both mobilization and replenishment of SVs may be reduced by mitochondria depletion in $\mathrm{A} \beta$ flies, leading to the susceptibility to activity-induced synaptic fatigue and neural transmission failure in the polysynaptic pathway. Moreover, SV depletion in the presynaptic terminal in aged
$\mathrm{A} \beta$ flies may also result from the marked reduction of mitochondria in the axon, because anterograde SV transport requires ATP (Schroer et al., 1985; Llinás et al., 1989). Finally, ATP is required for other processes in the transmitter secretion machinery. The disassembly of ternary cis-SNAREs complex (Söllner et al., 1993), which demands high ATP consumption during high-frequency transmission, could be impaired in $\mathrm{A} \beta$-expressing flies attributable to presynaptic mitochondria depletion. Endocytic, autophagic, and lysosomal activities are high in synapses and along the axon (Nixon et al., 2008). A decrease in retrograde axonal transport caused by mitochondrial depletion could result in an accumulation of autophagic vacuoles and pre-lysosomes in the presynaptic terminal, which might contribute to the accumulation of large vacuoles in our aged $\mathrm{A} \beta$ flies.

Significant depletion of presynaptic mitochondria occurred before obvious changes in synaptic transmission and other synaptic ultrastructure in $\mathrm{A} \beta$ flies. This phenomena is reminiscent of the dramatic mitochondria dysfunction/ATP reduction that occurs 2-3 months before neuritic degeneration in AD mice (Blanchard et al., 2003; Eckert et al., 2008; Hauptmann et al., 2009) and the metabolic decline (glucoses utility and oxygen consumption) in nondemented individuals genetically at risk for AD (Bookheimer et al., 2000; Small et al., 2000). Thus, although ATP reduction could be a consequence of mitochondria dysfunction associated with neurodegeneration (Lustbader et al., 2004; Yan and Stern, 2005; Lin and Beal, 2006; Du et al., 2008), it could also be prerequisite for the $\mathrm{A} \beta$ accumulation-induced neuropathological changes. Indeed, $A \beta$ induced neurotoxicity in primary culture neurons correlates with the basal ATP level of the cell before A $\beta$ application (Simakova and Arispe, 2007).

Together, we generated an AD model for investigating agedependent alterations of axonal and presynaptic function and ultrastructure induced by accumulation of $\mathrm{A} \beta$ at the identified single-neuron level. Accumulation of $\mathrm{A} \beta$ may inhibit mitochondria fission and in turn mitochondria biogenesis, leading to a range of age-dependent changes in the function and structure of both axon and presynaptic terminal. Therefore, our finding may uncover a new major component or cellular mechanism of $\mathrm{AD}$ pathogenesis.

\section{References}

Allen MJ, Shan X, Caruccio P, Froggett SJ, Moffat KG, Murphey RK (1999) Targeted expression of truncated glued disrupts giant fiber synapse formation in Drosophila. J Neurosci 19:9374-9384.

Bilen J, Bonini NM (2005) Drosophila as a model for human neurodegenerative disease. Annu Rev Genet 39:153-171.

Blanchard V, Moussaoui S, Czech C, Touchet N, Bonici B, Planche M, Canton T, Jedidi I, Gohin M, Wirths O, Bayer TA, Langui D, Duyckaerts C, Tremp G, Pradier L (2003) Time sequence of maturation of dystrophic neurites associated with Abeta deposits in APP/PS1 transgenic mice. Exp Neurol 184:247-263.

Bookheimer SY, Strojwas MH, Cohen MS, Saunders AM, Pericak-Vance MA, Mazziotta JC, Small GW (2000) Patterns of brain activation in people at risk for Alzheimer's disease. N Engl J Med 343:450-456.

Cauchi RJ, van den Heuvel M (2006) The fly as a model for neurodegenerative diseases: is it worth the jump? Neurodegener Dis 3:338-356.

Chapman PF, White GL, Jones MW, Cooper-Blacketer D, Marshall VJ, Irizarry M, Younkin L, Good MA, Bliss TV, Hyman BT, Younkin SG, Hsiao KK (1999) Impaired synaptic plasticity and learning in aged amyloid precursor protein transgenic mice. Nat Neurosci 2:271-276.

Crowther DC, Kinghorn KJ, Miranda E, Page R, Curry JA, Duthie FA, Gubb DC, Lomas DA (2005) Intraneuronal Abeta, non-amyloid aggregates and neurodegeneration in a Drosophila model of Alzheimer's disease. Neuroscience 132:123-135.

Du H, Guo L, Fang F, Chen D, Sosunov AA, McKhann GM, Yan Y, Wang C, 
Zhang H, Molkentin JD, Gunn-Moore FJ, Vonsattel JP, Arancio O, Chen JX, Yan SD (2008) Cyclophilin D deficiency attenuates mitochondrial and neuronal perturbation and ameliorates learning and memory in Alzheimer's disease. Nat Med 14:1097-1105.

Eckert A, Hauptmann S, Scherping I, Rhein V, Müller-Spahn F, Götz J, Müller WE (2008) Soluble beta-amyloid leads to mitochondrial defects in amyloid precursor protein and tau transgenic mice. Neurodegener Dis 5:157-159.

Fayyazuddin A, Zaheer MA, Hiesinger PR, Bellen HJ (2006) The nicotinic acetylcholine receptor Dalpha7 is required for an escape behavior in Drosophila. PLoS Biol 4:e63.

Finelli A, Kelkar A, Song HJ, Yang H, Konsolaki M (2004) A model for studying Alzheimer's Abeta42-induced toxicity in Drosophila melanogaster. Mol Cell Neurosci 26:365-375.

Fitzjohn SM, Morton RA, Kuenzi F, Rosahl TW, Shearman M, Lewis H, Smith D, Reynolds DS, Davies CH, Collingridge GL, Seabrook GR (2001) Agerelated impairment of synaptic transmission but normal long-term potentiation in transgenic mice that overexpress the human APP695SWE mutant form of amyloid precursor protein. J Neurosci 21:4691-4698.

Glenner GG, Wong CW (1984) Alzheimer's disease: initial report of the purification and characterization of a novel cerebrovascular amyloid protein. Biochem Biophys Res Commun 120:885-890.

Götz J, Ittner LM (2008) Animal models of Alzheimer's disease and frontotemporal dementia. Nat Rev Neurosci 9:532-544.

Gouras GK, Almeida CG, Takahashi RH (2005) Intraneuronal Abeta accumulation and origin of plaques in Alzheimer's disease. Neurobiol Aging 26:1235-1244.

Greeve I, Kretzschmar D, Tschäpe JA, Beyn A, Brellinger C, Schweizer M, Nitsch RM, Reifegerste R (2004) Age-dependent neurodegeneration and Alzheimer-amyloid plaque formation in transgenic Drosophila. J Neurosci 24:3899-3906.

Gureviciene I, Ikonen S, Gurevicius K, Sarkaki A, van Groen T, Pussinen R, Ylinen A, Tanila H (2004) Normal induction but accelerated decay of LTP in APP + PS1 transgenic mice. Neurobiol Dis 15:188-195.

Hardy J, Selkoe DJ (2002) The amyloid hypothesis of Alzheimer's disease: progress and problems on the road to therapeutics. Science 297:353-356.

Hauptmann S, Scherping I, Dröse S, Brandt U, Schulz KL, Jendrach M, Leuner K, Eckert A, Müller WE (2009) Mitochondrial dysfunction: an early event in Alzheimer pathology accumulates with age in AD transgenic mice. Neurobiol Aging 30:1574-1586.

Hirai K, Aliev G, Nunomura A, Fujioka H, Russell RL, Atwood CS, Johnson AB, Kress Y, Vinters HV, Tabaton M, Shimohama S, Cash AD, Siedlak SL, Harris PL, Jones PK, Petersen RB, Perry G, Smith MA (2001) Mitochondrial abnormalities in Alzheimer's disease. J Neurosci 21:3017-3023.

Hsia AY, Masliah E, McConlogue L, Yu GQ, Tatsuno G, Hu K, Kholodenko D, Malenka RC, Nicoll RA, Mucke L (1999) Plaque-independent disruption of neural circuits in Alzheimer's disease mouse models. Proc Natl Acad Sci U S A 96:3228-3233.

Huang FD, WoodruffE, Mohrmann R, Broadie K (2006) Rolling blackout is required for synaptic vesicle exocytosis. J Neurosci 26:2369-2379.

Iijima-Ando K, Hearn SA, Granger L, Shenton C, Gatt A, Chiang HC, Hakker I, Zhong Y, Iijima K (2008) Overexpression of neprilysin reduces alzheimer amyloid-beta42 (Abeta42)-induced neuron loss and intraneuronal Abeta42 deposits but causes a reduction in cAMP-responsive elementbinding protein-mediated transcription, age-dependent axon pathology, and premature death in Drosophila. J Biol Chem 283:19066-19076.

Ikeda K, Koenig JH, Tsuruhara T (1980) Organization of identified axons innervating the dorsal longitudinal flight muscle of Drosophila melanogaster. J Neurocytol 9:799-823.

Jacobsen JS, Wu CC, Redwine JM, Comery TA, Arias R, Bowlby M, Martone R, Morrison JH, Pangalos MN, Reinhart PH, Bloom FE (2006) Earlyonset behavioral and synaptic deficits in a mouse model of Alzheimer's disease. Proc Natl Acad Sci U S A 103:5161-5166.

Jolas T, Zhang XS, Zhang Q, Wong G, Del Vecchio R, Gold L, Priestley T (2002) Long-term potentiation is increased in the CA1 area of the hippocampus of APP(swe/ind) CRND8 mice. Neurobiol Dis 11:394-409.

Kang J, Lemaire HG, Unterbeck A, Salbaum JM, Masters CL, Grzeschik KH, Multhaup G, Beyreuther K, Müller-Hill B (1987) The precursor of Alzheimer's disease amyloid A4 protein resembles a cell-surface receptor. Nature 325:733-736.

King DG, Wyman RJ (1980) Anatomy of the giant fibre pathway in Dro- sophila. I. Three thoracic components of the pathway. J Neurocytol 9:753-770.

Kuromi H, Kidokoro Y (2002) Selective replenishment of two vesicle pools depends on the source of $\mathrm{Ca}^{2+}$ at the Drosophila synapse. Neuron 35:333-343.

LaFerla FM, Green KN, Oddo S (2007) Intracellular amyloid-beta in Alzheimer's disease. Nat Rev Neurosci 8:499-509.

Larson J, Lynch G, Games D, Seubert P (1999) Alterations in synaptic transmission and long-term potentiation in hippocampal slices from young and aged PDAPP mice. Brain Res 840:23-35.

Lin MT, Beal MF (2006) Mitochondrial dysfunction and oxidative stress in neurodegenerative diseases. Nature 443:787-795.

Llinás R, Sugimori M, Lin JW, Leopold PL, Brady ST (1989) ATPdependent directional movement of rat synaptic vesicles injected into the presynaptic terminal of squid giant synapse. Proc Natl Acad Sci U S A 86:5656-5660.

Lue LF, Kuo YM, Roher AE, Brachova L, Shen Y, Sue L, Beach T, Kurth JH, Rydel RE, Rogers J (1999) Soluble amyloid beta peptide concentration as a predictor of synaptic change in Alzheimer's disease. Am J Pathol 155:853-862.

Lustbader JW, Cirilli M, Lin C, Xu HW, Takuma K, Wang N, Caspersen C, Chen X, Pollak S, Chaney M, Trinchese F, Liu S, Gunn-Moore F, Lue LF, Walker DG, Kuppusamy P, Zewier ZL, Arancio O, Stern D, Yan SS, Wu H (2004) ABAD directly links Abeta to mitochondrial toxicity in Alzheimer's disease. Science 304:448-452.

Manczak M, Anekonda TS, Henson E, Park BS, Quinn J, Reddy PH (2006) Mitochondria are a direct site of A beta accumulation in Alzheimer's disease neurons: implications for free radical generation and oxidative damage in disease progression. Hum Mol Genet 15:1437-1449.

Marsh JL, Thompson LM (2006) Drosophila in the study of neurodegenerative disease. Neuron 52:169-178.

McLean CA, Cherny RA, Fraser FW, Fuller SJ, Smith MJ, Beyreuther K, Bush AI, Masters CL (1999) Soluble pool of Abeta amyloid as a determinant of severity of neurodegeneration in Alzheimer's disease. Ann Neurol 46:860-866.

Morgan D, Diamond DM, Gottschall PE, Ugen KE, Dickey C, Hardy J, Duff K, Jantzen P, DiCarlo G, Wilcock D, Connor K, Hatcher J, Hope C, Gordon M, Arendash GW (2000) A beta peptide vaccination prevents memory loss in an animal model of Alzheimer's disease. Nature 408:982-985.

Mucke L, Masliah E, Yu GQ, Mallory M, Rockenstein EM, Tatsuno G, Hu K, Kholodenko D, Johnson-Wood K, McConlogue L (2000) High-level neuronal expression of $\mathrm{A} \beta 1-42$ in wild-type human amyloid protein precursor transgenic mice: synaptotoxicity without plaque formation. J Neurosci 20:4050-4058.

Murakami K, Irie K, Morimoto A, Ohigashi H, Shindo M, Nagao M, Shimizu T, Shirasawa T (2002) Synthesis, aggregation, neurotoxicity, and secondary structure of various A beta 1-42 mutants of familial Alzheimer's disease at positions 21-23. Biochem Biophys Res Commun 294:5-10.

Nilsberth C, Westlind-Danielsson A, Eckman CB, Condron MM, Axelman K, Forsell C, Stenh C, Luthman J, Teplow DB, Younkin SG, Näslund J, Lannfelt L (2001) The "Arctic" APP mutation (E693G) causes Alzheimer's disease by enhanced Abeta protofibril formation. Nat Neurosci 4:887-893.

Nixon RA, Yang DS, Lee JH (2008) Neurodegenerative lysosomal disorders: a continuum from development to late age. Autophagy 4:590-599.

Oddo S, Caccamo A, Shepherd JD, Murphy MP, Golde TE, Kayed R, Metherate R, Mattson MP, Akbari Y, LaFerla FM (2003) Tripletransgenic model of Alzheimer's disease with plaques and tangles: intracellular Abeta and synaptic dysfunction. Neuron 39:409-421.

Pike CJ, Burdick D, Walencewicz AJ, Glabe CG, Cotman CW (1993) Neurodegeneration induced by beta-amyloid peptides in vitro: the role of peptide assembly state. J Neurosci 13:1676-1687.

Pilling AD, Horiuchi D, Lively CM, Saxton WM (2006) Kinesin-1 and Dynein are the primary motors for fast transport of mitochondria in Drosophila motor axons. Mol Biol Cell 17:2057-2068.

Reddy PH, Beal MF (2008) Amyloid beta, mitochondrial dysfunction and synaptic damage: implications for cognitive decline in aging and Alzheimer's disease. Trends Mol Med 14:45-53.

Scheff SW, Price DA (2006) Alzheimer's disease-related alterations in synaptic density: neocortex and hippocampus. J Alzheimers Dis 9 [Suppl 3]:101-115. 
Schroer TA, Brady ST, Kelly RB (1985) Fast axonal transport of foreign synaptic vesicles in squid axoplasm. J Cell Biol 101:568-572.

Selkoe DJ (2001) Alzheimer's disease: genes, proteins, and therapy. Physiol Rev 81:741-766.

Selkoe DJ (2002) Alzheimer's disease is a synaptic failure. Science 298:789-791.

Selkoe DJ (2008) Soluble oligomers of the amyloid beta-protein impair synaptic plasticity and behavior. Behav Brain Res 192:106-113.

Shankar GM, Li S, Mehta TH, Garcia-Munoz A, Shepardson NE, Smith I, Brett FM, Farrell MA, Rowan MJ, Lemere CA, Regan CM, Walsh DM, Sabatini BL, Selkoe DJ (2008) Amyloid-beta protein dimers isolated directly from Alzheimer's brains impair synaptic plasticity and memory. Nat Med 14:837-842.

Shen J, Kelleher RJ 3rd (2007) The presenilin hypothesis of Alzheimer's disease: evidence for a loss-of-function pathogenic mechanism. Proc Natl Acad Sci U S A 104:403-409.

Simakova O, Arispe NJ (2007) The cell-selective neurotoxicity of the Alzheimer's $A \beta$ peptide is determined by surface phosphatidylserine and cytosolic ATP levels. Membrane binding is required for $\mathrm{A} \beta$ toxicity. J Neurosci 27:13719-13729.

Small DH, Mok SS, Bornstein JC (2001) Alzheimer's disease and Abeta toxicity: from top to bottom. Nat Rev Neurosci 2:595-598.

Small GW, Ercoli LM, Silverman DH, Huang SC, Komo S, Bookheimer SY, Lavretsky H, Miller K, Siddarth P, Rasgon NL, Mazziotta JC, Saxena S, Wu HM, Mega MS, Cummings JL, Saunders AM, Pericak-Vance MA, Roses AD, Barrio JR, Phelps ME (2000) Cerebral metabolic and cognitive decline in persons at genetic risk for Alzheimer's disease. Proc Natl Acad Sci U S A 97:6037-6042.

Söllner T, Whiteheart SW, Brunner M, Erdjument-Bromage H, Geromanos S, Tempst P, Rothman JE (1993) SNAP receptors implicated in vesicle targeting and fusion. Nature 362:318 -324.

Sze CI, Troncoso JC, Kawas C, Mouton P, Price DL, Martin LJ (1997) Loss of the presynaptic vesicle protein synaptophysin in hippocampus correlates with cognitive decline in Alzheimer disease. J Neuropathol Exp Neurol 56:933-944.

Takahashi RH, Almeida CG, Kearney PF, Yu F, Lin MT, Milner TA, Gouras GK (2004) Oligomerization of Alzheimer's $\beta$-amyloid within processes and synapses of cultured neurons and brain. J Neurosci 24:3592-3599.
Tanzi RE, Bertram L (2005) Twenty years of the Alzheimer's disease amyloid hypothesis: a genetic perspective. Cell 120:545-555.

Tanzi RE, Gusella JF, Watkins PC, Bruns GA, St George-Hyslop P, Van Keuren ML, Patterson D, Pagan S, Kurnit DM, Neve RL (1987) Amyloid beta protein gene: cDNA, mRNA distribution, and genetic linkage near the Alzheimer locus. Science 235:880-884.

Terry RD, Masliah E, Salmon DP, Butters N, DeTeresa R, Hill R, Hansen LA, Katzman R (1991) Physical basis of cognitive alterations in Alzheimer's disease: synapse loss is the major correlate of cognitive impairment. Ann Neurol 30:572-580.

Verstreken P, Ly CV, Venken KJ, Koh TW, Zhou Y, Bellen HJ (2005) Synaptic mitochondria are critical for mobilization of reserve pool vesicles at Drosophila neuromuscular junctions. Neuron 47:365-378.

Walsh DM, Klyubin I, Fadeeva JV, Cullen WK, Anwyl R, Wolfe MS, Rowan MJ, Selkoe DJ (2002) Naturally secreted oligomers of amyloid beta protein potently inhibit hippocampal long-term potentiation in vivo. Nature 416:535-539.

Weiner HL, Frenkel D (2006) Immunology and immunotherapy of Alzheimer's disease. Nat Rev Immunol 6:404-416.

Wirths O, Multhaup G, Czech C, Feldmann N, Blanchard V, Tremp G, Beyreuther K, Pradier L, Bayer TA (2002) Intraneuronal APP/A beta trafficking and plaque formation in beta-amyloid precursor protein and presenilin-1 transgenic mice. Brain Pathol 12:275-286.

Wirths O, Multhaup G, Bayer TA (2004) A modified beta-amyloid hypothesis: intraneuronal accumulation of the beta-amyloid peptide- the first step of a fatal cascade. J Neurochem 91:513-520.

Wirths O, Weis J, Kayed R, Saido TC, Bayer TA (2007) Age-dependent axonal degeneration in an Alzheimer mouse model. Neurobiol Aging 28:1689-1699.

Yan SD, Stern DM (2005) Mitochondrial dysfunction and Alzheimer's disease: role of amyloid-beta peptide alcohol dehydrogenase (ABAD). Int J Exp Pathol 86:161-171.

Yankner BA, Duffy LK, Kirschner DA (1990) Neurotrophic and neurotoxic effects of amyloid beta protein: reversal by tachykinin neuropeptides. Science 250:279-282.

Zhang H, Gong B, Liu S, Fá M, Ninan I, Staniszewski A, Arancio O (2005) Synaptic fatigue is more pronounced in the APP/PS1 transgenic mouse model of Alzheimer's disease. Curr Alzheimer Res 2:137-140. 